\title{
Dr. Palkovits Miklós köszöntése 85. születésnapja alkalmából
}

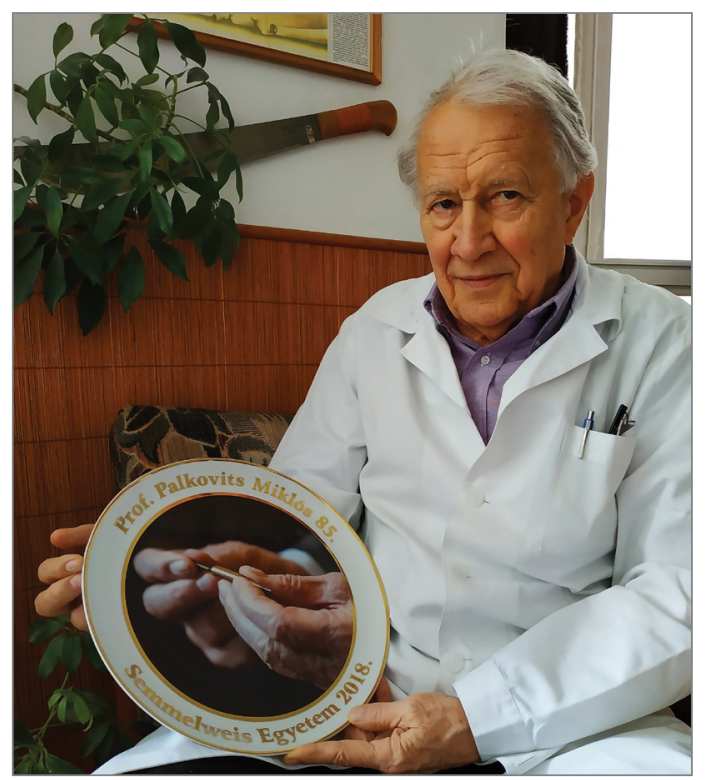

Dr. Palkovits Miklós professor emeritus, a Magyar Tudományos Akadémia rendes tagja 2018. december 5-én volt 85 éves. Ehhez a jubileumi ünnepi alkalomhoz méltó módon köszöntötték őt a Semmelweis Egyetem vezetői, a Magyar Anatómus Társaság vezetősége, az Anatómiai, Szövet- és Fejlődéstani Intézet munkatársai, Palkovits professzor akadémiai kutatótársai, munkatársai, tanítványai és barátai.

Életútja kora ifjúsági éveitől kezdve egyetemi hallgatóként a Semmelweis Egyetemhez kötötte. Harmadévesen, kinevezett demonstrátorként már oktat, ahol jelenleg is aktív mint a Semmelweis Egyetem Humán Agyszövet Bank vezetője. Az elmúlt 65 évben Palkovits professzor pályája és az alma mater története szorosan összefonódik. Számos agyterület és agypálya funkcionális topográfiai leírása mellett azok kémiai azonosításában is részt vett, így Palkovits Miklós a kémiai neuroanatómia egyik megteremtőjévé vált. Ami tudományos teljesítményét a legjobban mutatja, az nem csupán az általa írt 8 könyv, 59 könyvfejezet és 747 folyóiratcikk, hanem ezek kiemelkedő tudományos értéke, ugyanis közleményeinek összes idézettsége több mint 46 000, Hirsch-indexe
106. Emellett létrehozta a Semmelweis Egyetemen a Humán Agyszövet Bankot, amely az egész világon egyedülálló módon, fagyasztva mikrodisszektált agymintákat biztosít idegtudományi alapkutatást végző agykutatók számára.

Tudományos munkássága mellett tudományszervezésben is segítette ismereteivel, nemzetközi tekintélyével a magyar tudományt, a magyar orvostudományt. Számos nemzetközi tudományos folyóirat szerkesztése mellett, több magyar tudományos folyóiratnak, többek között az Orvosi Hetilapnak is dolgozott, a nemzetközi szerkesztőbizottság elnöke volt. Rendszeresen szervezett nemzetközi konferenciákat Magyarországon, ezekre - személyes meghívására - a legnevesebb külföldi előadók jöttek el előadásokat tartani. A Magyar Anatómus Társaságnak a főtitkára, a Magyar Idegtudományi Társaságnak az elnöke volt éveken keresztül. Kiemelkedő szerepe volt 1993-ban a Semmelweis Egyetem Idegtudományi Doktori Iskolájának megalapításában, az első PhD-kurzust ő tartotta Magyarországon. A Magyar Tudományos Akadémia Doktori Tanácsának elnökeként nagyon sokat tett azért, hogy az MTA doktori fokozat megszerzésének minimumkritériumai egyértelműen és pontosan rögzítve legyenek, így annak tudományos értéke mindenkor magas legyen.

Palkovits Miklós professzor úr büszke arra, hogy az elmúlt közel fél évszázad alatt nagyon sok fiatal kutató útját egyengette. Eddig 49 kandidátusi, illetve $\mathrm{PhD}$-fokozatú kutatónak volt a témavezetője, az 50. doktorandusz tanítványának munkáját jelenleg is irányítja. Hogy milyen sikeres volt a professzor úr témavezetóként is, jelzi, hogy tanítványai közül 14-en lettek tanszékvezető egyetemi tanárok Magyarországon, Európában, illetve az Egyesült Államokban.

A 85. születésnapi ünnepségén elhangzott köszöntőkből az is kiderült, hogy Palkovits Miklós tudomány iránti lelkesedése egyedülálló, amivel példát mutat az egész tudományos közösség számára.

Isten éltesse sokáig Professzor Urat!

Dobolyi Árpád dr. és Renner Éva dr. 